\author{
DOI 10.31558/2307-2318.2020.2.9 \\ УДК: 338.242 .2 \\ JEL: M20
}

\author{
Лемешко М.O., \\ аспірант, \\ Донецький національний університет імені Василя Стуса \\ ORCID: 0000-0002-2845-6750 \\ m.lemeshko@donnu.edu.ua \\ Лактіонова О.А., \\ д.е.н., доцент кафедри фінансів та банківської справи \\ Донецький національний університет імені Василя Стуса \\ ORCID: 0000-0001-6472-6503 \\ laktionova.loa@donnu.edu.ua
}

\title{
ЕКОСИСТЕМА ПІДТРИМКИ БІЗНЕСУ В УМОВАХ ПАНДЕМІЇ COVID-19 В УКРАЇНI ТА В ОКРЕМИХ КРАЇНАХ СС
}

Пандемія в иілому ряді регіонів планети поставила виклик розвитку економіки та ініціювала швидкі зміни, як в діловій, так $і$ в побутовій сферах життя людей. Наростаюча невизначеність щзодо наслідків пандемії для економіки змусила уряди країн швидко адаптуватися та впроваджувати заходи підтримки бізнесу, особливо тих сфер, які постраждали найбільше - туризм, промисловість, сфера гостинності та ін. Найбільш постраждалі від пандемії сектори малого та середнього бізнесу були вимушені призупинити діяльність й в цих умовах вкрай необхідна державна підтримка.

В статті розглянуто проблему підтримки бізнесу з точку зору концепиіі екосистем. Дано визначення екосистеми підтримки бізнесу, базуючись на конщепції бізнес-екосистем. Визначено основні групи та види екосистеми підтримки бізнесу. Розглянуто стан екосистеми підтримки бізнесу до впровадження обмежуючих заходів (2019 рік) та після (II-IV квартали 2020 року). Описуються заходи підтримки бізнесу, які були впроваджені в Україні після активної фази розповсюдження COVID-19. Проаналізовано заходи підтримки бізнесу в окремих країнах ЄС - Болгарії, Румунії, Угорщині та визначено спільні та відмінні риси з підтримкою в Україні. Визначено заходи, спрямовані на посилення діючих механізмів підтримки бізнесу в Україні з метою посилення ролі екосистеми підтримки бізнесу в відновлені економіки краӥни за рахунок удосконалення інструментарію базуючись на досвіді країн СС.

Ключові слова: екосистема, бізнес-екосистема, підтримка бізнесу, екосистема підтримки бізнесу, пандемія COVID-19

Рис. - 2, Табл. - 3, Літ. - 24 
Лемешко М.О., аспирант,

Донецкий национальный университет имени Василия Стуса

ORCID: 0000-0002-2845-6750

m.lemeshko@donnu.edu.ua

Лактионова А.А.

д.э.н., доцент кафедры финансов и банковского дела

Донецкий национальный университет имени Василя Стуса

ORCID: 0000-0001-6472-6503

laktionova.loa@donnu.edu.ua

\section{ЭКОСИСТЕМА ПОДДЕРЖКИ БИЗНЕСА В УСЛОВИЯХ ПАНДЕМИИ СОVID-19 В УКРАИНЕ И В ОТДЕЛЬНЫХ CTPAHAX EC}

Пандемия в целом ряде регионов планеты поставила вызов развитию экономики и инициировала быстрые изменения как в деловой, так и в бытовой сферах жизни людей. Нарастающая неопределенность последствий пандемии для экономики заставила правительства стран быстро адаптироваться и внедрять меры поддержки бизнеса, особенно тех сфер, которые пострадали больше всего - туризм, промылиленность, HoReCa и др. Наиболее пострадавшие от пандемии сектора малого и среднего бизнеса были вынуждены приостановить деятельность и в этих условиях крайне необходима государственная поддержка.

В статье предлагается взглянуть на вопрос поддержки бизнеса с точки зрения кониепции экосистем. В статье дается определение экосистемы поддержки бизнеса, основываясь на концепчии бизнес-экосистем. Определены основные группь и виды экосистемы поддержки бизнеса. Рассмотрено состояние экосистемы поддержки бизнеса до внедрения ограничивающих мероприятий (2019) и после (II-IV кварталь 2020 года). Описываются меры поддержки бизнеса, которые были внедрены в Украине после активной фазы распространения COVID-19. Рассмотрены меры поддержки бизнеса в отдельных странах ЕС и описаны их основные положения. Рассмотрены направления и виды поддержки бизнеса в Болгарии, Румынии, Венгрии и определены общие и отличительные черты с поддержкой в Украине. Предложены меры, направленные на расширение действующих механизмов поддержки бизнеса в Украине с целью усиления роли экосистемы поддержки бизнеса в восстановлении экономики страны за счет усовершенствования инструментария основываясь на опыте стран ЕС.

Ключевые слова: экосистема, бизнес-экосистема, поддержка бизнеса, экосистема поддержки бизнеса, пандемия COVID-19

Рис. - 2, Табл. - 3, Лит. - 24 


\author{
M. Lemeshko \\ Postgraduate student, \\ Vasyl Stus Donetsk National University \\ ORCID: 0000-0002-2845-6750 \\ m.lemeshko@donnu.edu.ua
}

O. Laktionova

Doctor of Economic Sciences, Associate Professor

Department of Finance and Banking

Vasyl Stus Donetsk National University

ORCID: 0000-0001-6472-6503

laktionova.loa@donnu.edu.ua

\title{
BUSINESS SUPPORT ECOSYSTEM UNDER PANDEMIC COVID-19 IN UKRAINE AND EU IN SOME COUNTRIES
}

Pandemic in many regions of the planet has put the challenge to the economy and initiated the rapid changes in business and in everyday life. The growing uncertainty about the consequences of the pandemic for the economy forced the governments of the countries to quickly adapt and implement measures to support business, especially in those areas that were most affected - tourism, industry, HoReCa, etc. Most affected by the pandemic, the sector of small and medium-sized businesses has been forced to suspend activities in these conditions is extremely necessary state support.

The article proposes to look at the issue of business support from the point of view of the concept of ecosystems. The article defines a business support ecosystem based on the concept of business ecosystems. The main groups and types of business support ecosystem have been identified. The state of the business support ecosystem before the implementation of restrictive measures (2019) and after (II-IV quarters of 2020) was considered. Describes the business support measures that were introduced in Ukraine after the active phase of the spread of COVID-19. Business support measures in individual EU countries are considered and their main provisions are described. The directions and types of business support in Bulgaria, Romania, Hungary are considered and common and distinctive features with support in Ukraine are identified. Measures have been identified to strengthen the existing business support mechanisms in Ukraine in order to strengthen the role of the business support ecosystem in the country's restored economies by improving the tools based on the experience of the EU countries.

Keywords: ecosystem, business ecosystem, business support, business support ecosystem, COVID-19 pandemic

Fig. -2 , Tabl. -3 , Ref. -24 .

Постановка проблеми. Сьогоднішня економічна криза, пов'язана із спалахом коронавірусу COVID-19 у лютому 2020 року, стала рушійною силою щодо зміни соціально-економічних тенденції та політичних векторів багатьох країн сучасного світу. В той же час, для України залишається актуальною проблематика підтримки малого та середнього бізнесу, яка в умовах обмежень пандемії повинна бути трансформована під нові реалії. Невирішеною залишається також проблематика напрацювання інструментарію підтримки бізнесу в кризових умовах в Україні. В статті пропонується поглянути на зазначену проблематику з точки зору концепцій екосистем. 
Аналіз останніх досліджень і публікацій. Ідеї розгляду підприємництва як взаємозв'язаної системи або аспекти дослідження щодо причин та наслідків взаємодії бізнесу та інших організацій можна знайти в роботах М. Портера, Р. Нельсона та С. Вінтера, М. Якобідеса, К.Ченнано, А. Гаввер, Д. Мур. Вагомий внесок у дослідження проблем функціонування та розвитку малого підприємництва зробили такі вітчизняні вчені, як К. Ващенко, 3. Варналій, Е. Лібанова та ін.

Формулювання цілей статті. Стаття має на меті дати визначення екосистеми підтримки бізнесу в Україні під час пандемії COVID-19 та запропонувати шляхи іiі удосконалення на основі співставлення iï інструментів з аналогічними в країнах ЄC.

Виклад основного матеріалу. В професійному та наукові середовищі сформувалася майже однозначна думка щодо важкості економічної природи наслідків сучасної кризи, яка має не тільки явні збитки в період «lock down» або карантину, але i тривалу інерцію негативних впливів на економічний розвиток після відновлення економічної активності. Функціонуюча екосистема підтримки малого та середнього бізнесу на макро- та локальному або місцевому рівнях у докризовому періоді очевидно мала зазнати суттєвої швидкої трансформації як із позиції обсягів забезпечення, так і своєї змістовності - інструментів та механізмів впливу.

Наразі чіткого визначення поняттю «екосистема» не існує, та сам механізм його функціонування залишається у форматі концепту. Вперше поняття бізнес-екосистеми ввів James F. Moore в 1994 році в своїй статті Predators and prey: A new ecology of competition він запропонував дивитись на підприємництво не як на сукупність окремих одиниць, а я як на систему взаємозв'язків та усіх бізнесів та інших агентів ділового середовища [1]. Пізніше James F. Moore в 1998 році в роботі The New Corporate Form більш широко розкриває поняття та включає до бізнес-екосистеми спільноту клієнтів, постачальників, виробників, інших стейкхолдерів, які працюють у взаємозв'язку з метою виробництва товарів та надання послуг [2]. Сюди ж James F. Moore додає фінансові інституції, бізнес-асоціації, державні органи влади, урядові організації, профспілки та інших учасників бізнес-середовища.

Набагато пізніше, у 2013 році, George Foster та Carlos Shimizu в доповіді Entrepreneurial Ecosystems Around the Globe and Company Growth Dynamics надають наступні складові бізнес-екосистеми, до яких відносить людський капітал та людські ресурси, нормативно-правове регулювання, навчання, університети, систему підтримки, культуру підприємництва [3].

Отже, підсумовуючи вищевикладене, можна дати наступне визначення бізнесекосистемі - це комплекс зв'язків між людьми, суб'єктами господарювання, установами та нормативно-правовим полем, що об'єднує в собі як матеріальні та і нематеріальні складові в контексті сприяння розвитку підприємництва та забезпечення належного ділового клімату. До бізнес-екосистеми можна включати покупців, робітників, інші бізнеси, державні органи, законодавче регулювання відносин, фінансові організації, об'єднання та спілки підприємців, освітні установи. Логічно можна вважати, що екосистема підтримки бізнесу об'єднує в собі аспекти наведених компонентів. В той же час якорем та центральним елементом все одно залишається бізнес - мале та середнє підприємництво. Якщо бізнес-екосистема націлена на виробництво якісного продукту або послуги, то кінцевою метою екосистеми підтримки можна вважати максимізацію ефективності надання підтримки щодо розвитку малим та середнім підприємцям.

Отже, давши визначення бізнес-екосистемі та екосистемі підтримки бізнесу стає можливим визначити інструментарій останнього. Для проведення аналізу умовно розділимо його на такі групи та види: 
- Фінансова підтримка та доступ до грошей:

○ бізнес-орієнтованість банківської системи;

○ податкові пільги;

○ компенсації кредитів.

- Розвиток навичок та компетенцій:

○ бізнес-освіта;

○ інформаційно-комунікаційна інфраструктура підтримки;

○ сприяння експортній діяльності;

- Нормативно-правове забезпечення та інституційна спроможність:

○ спеціальні режими оподаткування;

○ регуляторні процедури;

○ забезпечення роботи урядових та неурядових установ підтримки підприємництва;

Для подальшого аналізу представлення зазначених інструментів у сьогоднішній системі підтримки бізнесу в Україні порівняємо наявні тренди до розширення або звуження представлених елементів екосистеми підтримки бізнесу в умовах змін викликаних COVID-19.

В таблиці 1 наведена характеристика стану екосистеми підтримки бізнесу в Україні, відповідно до наведених вище груп та видів.

Екосистема підтримки бізнесу 2019*

Таблиця 1

\begin{tabular}{|c|c|c|}
\hline Група & Вид & Станом на 2019 рік \\
\hline \multirow[t]{3}{*}{$\begin{array}{l}\text { Фінансова } \\
\text { підтримка та } \\
\text { доступ до грошей }\end{array}$} & $\begin{array}{l}\text { бізнес-орієнтованість } \\
\text { банківської системи }\end{array}$ & $\begin{array}{l}\text { Банківська система після кризи нарощує ефективності та сервіси } \\
\text { для бізнесу, однак через відносно високу облікову ставку НБУ } \\
\text { кредитування бізнесу ускладнено. }\end{array}$ \\
\hline & податкові пільги & Податкові пільги представлено обмежено. \\
\hline & компенсації кредитів & $\begin{array}{l}\text { В кінці } 2019 \text { року розроблено програму «Доступні кредити 5-7-9», } \\
\text { страт якої заплановано на } 1 \text {-й квартал } 2020 \text { року. } \\
\text { Наявні програми компенсації витрат на нове обладнання для } \\
\text { сільгоспвиробників. } \\
\begin{array}{l}\text { Компенсуються витрати на новостворені робочі місця за } \\
\text { спеціальним Порядком. }\end{array}\end{array}$ \\
\hline \multirow[t]{3}{*}{$\begin{array}{l}\text { Розвиток } \\
\text { навичок } \\
\text { компетенцій }\end{array}$} & бізнес-освіта & $\begin{array}{l}\text { Розвивається мережа бізнес-шкіл, інкубаторів, академій, програм } \\
\text { навчання підприємців з числа ВПО або ветеранів АТО/ООС. } \\
\text { Активну участь грають міжнародні донорські організації. }\end{array}$ \\
\hline & $\begin{array}{l}\text { інформаційно- } \\
\text { комунікаційна } \\
\text { інфраструктура підтримки }\end{array}$ & $\begin{array}{l}\text { Працює Офіс підтримки МСП при міністерстві економіки. } \\
\text { Розпочато створення порталу для підприємців Дія.Business. } \\
\text { Розвиваються ряд ініціатив місцевих органів влади. }\end{array}$ \\
\hline & $\begin{array}{l}\text { сприяння } \quad \text { експортній } \\
\text { діяльності }\end{array}$ & $\begin{array}{l}\text { Працює Офіс } 3 \text { просування експорту } 3 \text { метою навчання та } \\
\text { налагодження ділових зв’язків МСП з партнерами з інших країн. }\end{array}$ \\
\hline \multirow{3}{*}{$\begin{array}{l}\text { Нормативно- } \\
\text { правове } \\
\text { забезпечення та } \\
\text { інституційна } \\
\text { спроможність }\end{array}$} & $\begin{array}{l}\text { спеціальні } \\
\text { оподаткування }\end{array}$ & Діє спрощена система оподаткування. \\
\hline & регуляторні процедури & $\begin{array}{l}\text { Працює Офіс ефективного регулювання } 3 \text { метою покращення } \\
\text { регуляторного поля на державному рівні. }\end{array}$ \\
\hline & $\begin{array}{lr}\text { забезпечення } & \text { роботи } \\
\text { урядових та } & \text { неурядових } \\
\text { установ } & \text { підтримки } \\
\text { підприємництва }\end{array}$ & $\begin{array}{l}\text { Діє ряд законодавчих ініціатив щодо регламентації напрямів } \\
\text { підтримки МСП. Виділяється фінансування на діяльність } \\
\text { державних установ підтримки бізнесу. } \\
\text { Розвиваються бізнес-асоціації та об’єднання підприємців. }\end{array}$ \\
\hline
\end{tabular}

*складено авторами

Основними інструментами екосистеми підтримки бізнесу на сьогодні є спрощена 
система оподаткування, наявність механізмів фінансової підтримки та інституційна підтримка у вигляді ряду державних та недержавних установ й бізнес-асоціацій. В таблиці 2 наведена характеристика сучасного стану екосистеми підтримки бізнесу в Україні, відповідно до наведених вище груп та видів.

Таблиця 2

Екосистема підтримки бізнесу 2020*

\begin{tabular}{|c|c|c|c|}
\hline Група & & Вид & Станом на 2020 рік \\
\hline \multirow[t]{3}{*}{$\begin{array}{l}\text { Фінансова } \\
\text { підтримка } \\
\text { доступ } \\
\text { грошей }\end{array}$} & \multirow[t]{3}{*}{$\begin{array}{l}\text { та } \\
\text { до }\end{array}$} & $\begin{array}{l}\text { бізнес-орієнтованість } \\
\text { банківської системи }\end{array}$ & $\begin{array}{l}\text { Зменшення облікової ставки на початку року та у 2му кварталі } 2020 \\
\text { року мало б простимулювати кредитування бізнесу, однак через брак } \\
\text { ліквідних коштів кредитування бізнесу ускладнено. У порівняні } \\
\text { аналогічним періодом минулого року обсяг кредитування МСП } \\
\text { скоротився приблизно на } 15 \%\end{array}$ \\
\hline & & податкові пільги & $\begin{array}{l}\text { Введено цілий ряд податкових пільг по державним та місцевим } \\
\text { податкам як антикризові заходи на час пандемії }\end{array}$ \\
\hline & & компенсації кредитів. & $\begin{array}{l}\text { Удосконалено програму «Доступні кредити 5-7-9», залучено } \\
\text { додаткові банки-партнери, спрощено умови кредитування. } \\
\text { Збережено фінансування програм компенсації витрат на нове } \\
\text { обладнання для сільгоспвиробників. } \\
\text { Запроваджено компенсацію витрат оплату праці на час зупинки } \\
\text { бізнесу. }\end{array}$ \\
\hline \multirow[t]{3}{*}{$\begin{array}{l}\text { Розвиток } \\
\text { навичок } \\
\text { компетенцій }\end{array}$} & \multirow[t]{3}{*}{ та } & бізнес & $\begin{array}{l}\text { Через заходи боротьби з розповсюдженням вірусу призупинено } \\
\text { діяльність університетів, бізнес-шкіл, проведення навчальних } \\
\text { форумів та тренінгів. } \\
\text { Альтернатива - онлайн навчання, хоч и швидко розвивається, однак } \\
\text { не може повністю невілювати відсутність офлайн активностей. }\end{array}$ \\
\hline & & $\begin{array}{l}\text { інформаційно- } \\
\text { комунікаційна } \\
\text { інфраструктура } \\
\text { підтримки }\end{array}$ & $\begin{array}{l}\text { Працює Офіс підтримки МСП при міністерстві економіки } \\
\text { Запущено порталу для підприємців від Офіси розвитку МСП та } \\
\text { портал Дія.Business від Мінцифри. } \\
\text { Розвиваються ряд ініціатив місцевих органів влади. }\end{array}$ \\
\hline & & $\begin{array}{l}\text { сприяння } \quad \text { експортній } \\
\text { діяльності }\end{array}$ & $\begin{array}{l}\text { Працює Офіс з просування експорту, однак через обмежуючи заходи } \\
\text { експортна діяльність ускладнена. }\end{array}$ \\
\hline \multirow{3}{*}{\multicolumn{2}{|c|}{$\begin{array}{l}\text { Нормативно- } \\
\text { правове } \\
\text { забезпечення та } \\
\text { інституційна } \\
\text { спроможність }\end{array}$}} & $\begin{array}{l}\text { спеціальні } \\
\text { оподаткування }\end{array}$ & $\begin{array}{l}\text { Збільшено ліміти доходів суб’єктів господарювання на спрощеній } \\
\text { системі оподаткування. }\end{array}$ \\
\hline & & регуляторні процедури & $\begin{array}{l}\text { Працює Офіс ефективного регулювання } 3 \text { метою покращення } \\
\text { регуляторного поля на державному рівні. Запущено роботу Офісу } \\
\text { простих рішень } 3 \text { метою напрацювання концепцій реформ окремих } \\
\text { галузей економіки та покращенню ділового клімату та інвестиційної } \\
\text { привабливості. }\end{array}$ \\
\hline & & $\begin{array}{l}\text { забезпечення } \quad \text { роботи } \\
\text { урядових та неурядових } \\
\text { установ } \\
\text { підприємництва }\end{array}$ & $\begin{array}{l}\text { Забезпечено нормативно-правове регулювання розширення } \\
\text { механізмів підтримки бізнесу, фінансування таких інструментів. } \\
\text { Бізнес-асоціації та представники програм грантової допомоги } \\
\text { бізнесу переорієнтувались на просування ініціатив щодо підтримки } \\
\text { бізнесу в умовах COVID-19 та наданні грантової підтримки. }\end{array}$ \\
\hline
\end{tabular}

*складено авторами

Як бачимо, за напрямом податкових пільг, спрощеної системи оподаткування та наданню фінансової підтримки наявний прогрес розвитку інструментів. Однак по ряду факторів слід відзначити спад ефективності, зокрема, в експортній діяльності, навчання, банківській сфері, що відображено в таблиці 3.

Слід зазначити, що по таких факторах як підключення до електроенергії, якість судових рішень, швидкість оформлення документів для ведення бізнесу, прозорості експортно-імпортної діяльності та інших вагомих факторах, які безпосередньо впливають на якість ділового клімату покращення суттєвого не відбулося, що відображено у рейтингу Doing Business 2020 [4]. 
Таблиця 3

Екосистема підтримки бізнесу в Україні у порівнянні 2019 та 2020 років*

\begin{tabular}{|c|c|c|}
\hline Група & Вид & $\begin{array}{c}\text { Розширення або звуження } \\
\text { можливостей елементів екосистеми } \\
\text { підтримки бізнесу }\end{array}$ \\
\hline \multirow{3}{*}{$\begin{array}{l}\text { Фінансова підтримка } \\
\text { доступ до грошей }\end{array}$} & бізнес-орієнтованість банківської системи & $\langle= \pm=1$ \\
\hline & податкові пільги & \\
\hline & компенсації кредитів. & \\
\hline \multirow{3}{*}{$\begin{array}{l}\text { Розвиток навичок та } \\
\text { компетенцій }\end{array}$} & бізнес-освіта & $\because m=\square$ \\
\hline & $\begin{array}{l}\text { інформаційно-комунікаційна } \\
\text { інфраструктура підтримки }\end{array}$ & \\
\hline & сприяння експортній діяльності & $\langle= \pm=1$ \\
\hline \multirow{3}{*}{$\begin{array}{l}\text { Нормативно-правове } \\
\text { забезпечення та } \\
\text { iнституційна спроможність }\end{array}$} & спеціальні режими оподаткування & - \\
\hline & регуляторні процедури & $=$ \\
\hline & $\begin{array}{lrr}\text { забезпечення } & \text { роботи } & \text { урядових } \\
\text { неурядових } & \text { установ } \\
\text { підприємництва } & & \text { підтримки } \\
\end{array}$ & \\
\hline
\end{tabular}

*складено авторами

Таким чином, в Україні в період з 2019 по 2020 рр. мають тенденції до розширення: податкові пільги, компенсації кредитів, інформаційно-комунікаційна інфраструктура підтримки, спеціальні режими оподаткування, регуляторні процедури, забезпечення роботи урядових та неурядових установ підтримки підприємництва.

Слід зазначити, що незважаючи на наведені тенденції, бізнесу важко впоратись 3 наслідками обмежень під час пандемії, про що свідчать ряд опитувань. Свропейська Бізнес Асоціація в експрес-опитуванні демонструє наступні показники: майже половина компаній (48\%) вже в березні 2020 року зафіксувала від 20\% до 50\% втрат від доходів, $16 \%$ прийняли рішення про зміну заробітної плати персоналу, а $14 \%$ - про скорочення штату [5]. Станом на початок квітня 2020 р., компанії повідомляють про такі фінансові наслідки обмежувальних карантинних заходів для їхнього бізнесу: більшість компаній, а саме $70 \%$ опитаних зазнали до 50\% втрат від доходів, ще $18 \%$ повідомляють про 50 75\% втрат [6]. Згідно опитування Ernst\&Young 25\% компаній переглядали фінансові плани (бюджети) на 2020 рік у квітні в порівнянні з плановими значеннями на початок 2020 року та з них 89\% компаній планують перегляд у сторону зменшення, а $31 \%$ компаній заморожують підвищення заробітних плат на невизначений термін. Загалом 97\% частково або повністю перевели працівників працювати дистанційно, а 64\% компаній очікують негативний вплив поточної ситуації на виконання бізнес-цілей [7].

Регламентування та впровадження заходів підтримки бізнесу в Україні почалось 3 початку березня 2020 року. Так, згідно Закону України № 533-IX було заборонено проведення перевірок бізнесу до 30.06 .2020 р., як планових та і позапланових, на час карантинних заходів органами державного нагляду [8]. Крім того, з 18 березня 2020 року по останній місяць в якому діє карантин введено мораторій на податкові перевірки бізнесу [9]. Введено податкові канікули з ряду податків, а саме: плата за землю, податок на об’єкти нежитлової нерухомості, відмінні від земельної ділянки, звільнені від сплати соціальних внесків фізичні особи-підприємці, особи, які провадять незалежну професійну діяльність, члени фермерського господарства. Окрім того, цілий ряд міст України отримали можливість зменшити рішеннями органів місцевого самоврядування ряд місцевих податків і зборів - єдиний податок, плату за землю, податок на нерухоме 
майно, відмінне від земельної ділянки.

31 березня 2020 року було скасовано застосування штрафних санкцій до кінця карантину в Україні за несвоєчасну, неповну сплату єдиного внеску або за несвоєчасне подання звітності. Також, до 1 січня 2021 року відкладається застосування реєстраторів розрахункових операції платниками єдиного податку другої - четвертої груп, обсяг доходу яких за рік не перевищує 1 млн.

Постановою Кабміну від 22.04.2020 №306 було затверджено Порядок надання та повернення коштів, спрямованих на фінансування допомоги по частковому безробіттю на період карантину. Так, якщо роботодавець вимушений був скоротити працівників або тривалість робочого часу, то він має право отримати через центр занятості фінансову підтримку спрямовану на виплату працівникам різниці у заробітній платі. Допомога надається за кожну годину, на яку працівникові скорочено робочий час, 3 розрахунку 2/3 тарифної ставки, а розмір допомоги не може перевищувати розміру мінімальної заробітної плати (4723 грн). 3 початку дії відповідної норми (28.04.2020) по 31 серпня 2020 року роботодавцями подано 221 тис. пакетів документів, з яких прийнято 204 тис. позитивних рішень для охоплення виплатами 367 тис. громадян [10].

В Україні ще до початку карантинних обмежень почала діяти державна програма компенсації витрат за кредитами «Доступні кредити 5-7-9\%», яка отримала деякі зміни у зв'язку з необхідністю подолання кризи. Програма передбачає державну допомогу за кредитами на оборотний капітал, на рефінансування кредиту та на інвестиційні кредити. Передбачається наявність кредитних гарантії держави у розмірі 80\% від розміру кредиту, сам кредит до 3 млн грн на оборотний капітал можна отримати на строк до 2 років 3 процентною ставкою 3\%. Також, наявний механізм отримати рефінансування кредиту або інвестиційний кредит до 3 млн грн на строк до 5 років 3 процентною ставкою 5\% (при створенні робочих місць та доходом за рік до 50 млн грн), 7\% (якщо дохід за рік до 50 млн грн) та 9\% (якщо дохід 50-100 млн грн) [11]. Загалом, станом на кінець вересня 2020 року, видано в рамках державної програми «Доступні кредити 5-7-9\%» 3805 позик на загальну суму в 9,062 мільярда гривень [12].

Окрім того, в Україні діють більше 20 різних програм підтримки бізнесу від різних національних та міжнародних організацій, фондів та банків, які надають несистемну допомогу у вигляді цільових грантів, консультацій або навчання [13].

Отже бачимо, що переважну більшість заходів було регламентовано державою на початку розповсюдження в Україні COVID-19 та одночасно із запровадженням обмежуючих заходів, пов'язаних із вимушеним соціальним дистанціюванням. Більшість заходів несуть в собі нормативно-правове врегулювання заборони на перевірки бізнесу на час карантину, розширення можливостей спрощеної системи оподаткування. Окремо варто відзначити результати програми «Доступні кредити 5-7-9\%».

Для країн Європейського союзу діє затверджений Європейською комісією рамковий документ (EU State aid rules), який регламентує види державної підтримки економіки для країн членів на час пандемії COVID-19 [15]. У документі наголошується на необхідності подолати та максимально скоротити економічний шок, 3 якими стикнулися держави через пандемію. Загалом документ регламентує надання наступних видів підтримки бізнесу країнами-членами ЄС: прямі гранти або вибіркові податкові пільги, держані кредитні гарантії, компенсація витрат по кредитам, страхування експортних кредитів, підтримка галузі $\mathrm{R} \& \mathrm{D}$, підтримка підприємств, які задіяні в виробництві товарів пов'язаних з боротьбою з пандемією, окрім того передбачається для усіх сфер економіки пряма підтримки у вигляді відстрочки податкових платежів та соціальних внесків, а також для секторів які постраждали найбільше - субсидіювання 
витрат підприємств на оплату праці робітників.

Загалом, антикризові заходи країн ЄС отримають фінансування у розмірі 3,9 млрд євро, найбільша питома вага заходів буде профінансовано в рамках EU State aid rules, слід зауважити, що в більшості країн $Є С$ ці заходи будуть фінансуватись із структурних фондів Європейського союзу за погодженням Європейської комісії.

Для практичного розуміння заходів, які впроваджують в країнах ЄС й порівняння 3 Україною візьмемо наступні країни: Румунія, Болгарія та Угорщина. На наступних графіках відображені показники економічного розвитку країн на основі даних World Development Indicators Світового банку (рис. 1-2).

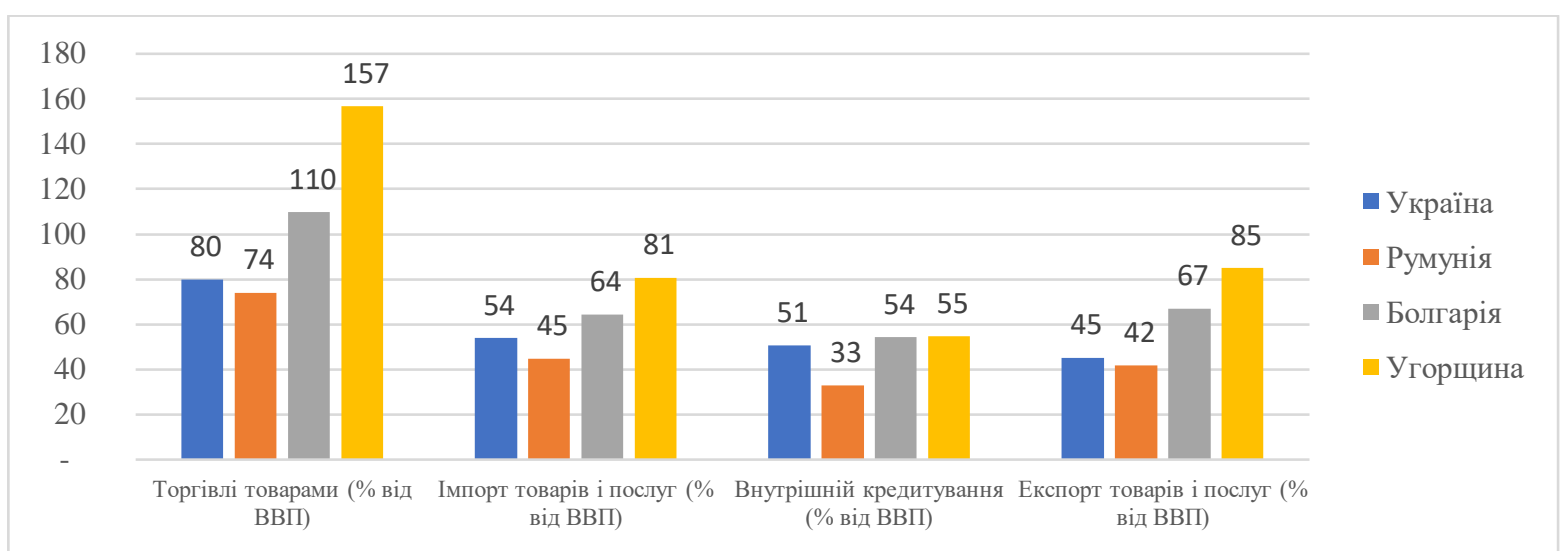

Рисунок 1. Показники економічного розвитку World Development Indicators 2018, \% від ВВП [15]



Рисунок 2. Показники економічного розвитку World Development Indicators 2018, $\%$ від ВВП [15]

Україна знаходиться приблизно на одному рівні з порівнювальними країнами по показниках: імпорт товарів і послуг (\% до ВВП), внутрішне кредитування (\% до ВВП), додана вартість в промисловості (\% до ВВП), податкових надходжень (\% до ВВП), темпи зростання ВВП. Це свідчить про можливість порівняння цих країн з точку зору ділової активності та відносно еквівалентної частки у ВВП кредитування, акумулювання податкових доходів та темпів зростання ВВП. Отже, за результатами порівняння ці країни географічно та економічно співставні із Україною, та їх можна розглядати із позиції компаративного аналізу механізмів підтримки бізнесу, які були запроваджені цими країнами.

Болгарія. Уряд Болгарії виділив загалом 2,3 млрд євро на заходи 3 підтримки 
місцевого бізнесу, який постраждав під час пандемії від обмежуючих заходів або втратив комерційні зв'язки. Окрім того, 435 млн євро зі структурних фондів СС направлено на фінансувати соціально-економічних заходів, включаючи фінансову підтримку МСП [16].

Для підтримки бізнесу сфери гостинності, транспорту, розваг, туризму, креативної індустрії та інших виділено 500 млн євро на покриття $60 \%$ витрат на заробітну плату працівників протягом трьох місяці для компаній, які не мають податкових боргів та зобов'язуються покривати 40\%-й залишок заробітної плати. Для підтримки галузі туризму введено спеціальну дотацію для туроператорів, які користуються місцевими авіаперевізниками, у розмірі 35 євро за одну місце в літаку, що використовується для перевезень туристів в Болгарію [15]. Для мікро та малих підприємств з усіх сфер діяльності із штатом працівників до 50 осіб, які були зареєстровані до 1-го липня 2019 року та оборот який впав більше, ніж на 20\% (у порівнянні із середнім за 2019 рік) діє грантова програма від 1500 євро до 5000 євро .

Для середніх підприємств, які зареєстровані до 1-го січня 2019 року та обсяг реалізованої продукції яких менший 1,5 млн євро, також діє програма надання грантів. Середні підприємства мають право запросити допомогу при нестачі грошових коштів або втрати достатнього рівня ліквідності через пандемію. Розмір допомоги може скласти від 15000 євро до 50000 євро, але не більше 1\% від чистого доходу за 2019 рік.

Bulgarian National Bank запровадив мораторій на платежі за банківськими кредитами на строк до 6 місяців, що включає витрати на обслуговування кредиту та покриття основної суми боргу [17]. Мікро бізнес та самозайняті особи, які мають обмежену кредитну історію та відносно нещодавно зареєстровані як бізнес, мають можливість отримати мікрокредити до 25000 євро на початок підприємницької діяльності [18]. Малі та середні підприємства мають можливість отримати кредит до 150 000 євро на поповнення обігових коштів під портфельні гарантії Болгарського банку розвитку. Основними вимогами участі для підприємств $є$ скорочення обороту бізнесу, наявна деібіторська заборгованість, заборгованість перед постачальниками, скасування експортно-імпортних контрактів та закриття виробництв або офісів [19].

3 1-го липня 2020 року до 31 грудня 2021 року в Болгарії скорочена більш ніж в два рази ставка ПДВ для окремих видів діяльності бізнесу, в тому числі туристичної галузі, - $320 \%$ до 9\%. В першу чергу це харчова галузь, ресторанний бізнес, книжкова галузь, а також для бізнесу дитячого харчування та предметів гігієни.

Угорщина 17 квітня 2020 року отримала погодження від Єврокомісії на фінансування заходів підтримки економіки на приблизно 1 млрд євро. Фонд відновлення економіки склав 3,8 млн євро (2,9\% ВВП). Окремо, Hungarian Tourism Agency виділила 2,8 млн євро на підтримку бізнесу галузі туризму [16].

Щодо субсидіювання заробітної плати наявна можливість отримати компенсацію для компаній зі сфери R\&D у розмірі 40\%. Також компанії, можуть наймати офіційно зареєстрованих тимчасово безробітних та протягом 6 місяців заробітну плату яким буде компенсувати держава у розмірі не більше 560 євро (включаючи соціальні відрахування) [22]. Окрім того, підприємства, які втратили можливість працювати, або які були вимушені призупинити частину виробництва на час зупинки діяльності можуть розраховувати на компенсацію у розмірі $60 \%$ від страхового доходу за січень (заробітна плата 3 якої здійснюються соціальні відрахування) на кожного працівника.

Сектори угорської економіки, які найбільше постраждали від пандемії COVID-19 звільнені від сплати податку на малий бізнес, а також від податків на заробітну плату та соціальних внесків. Тимчасово був скасований угорський податок (збір) на розвиток 
туризму (аналог туристичного податку в Україні).

На період з березня по червень 2020 року бізнес зі сфер гостинності, розваг, спорту, азартних ігор не повинен сплачувати свою частину внеску до спеціальних фондів соціального страхування із заробітних плат $(17,5 \%+1,5 \%)$ [21]. А з липня 2020 року скорочено на $2 \%$ розмір внеску на соціальне страхування до $15,5 \%$. Скасовано збір за користування громадською територією для бізнесу 3 ресторанної сфери (літні майданчики, тераси, благоустрій кафе). Фіскальні органи не будуть стягувати штрафні санкції з податкових заборгованостей підприємств, а повернення податку на додану вартість було прискорено з боку держави (для МСП з 75 днів до 30 днів 3 дати подання відповідної заяви) [16]. До 31 грудня 2020 року для підприємств запроваджено мораторій на оплату заборгованості за кредитними, лізинговими та іншими договорами займу. Для сектору малого та середнього підприємництва впроваджений механізм дешевого кредитування «NHP Наjrá!» 3 процентною ставку не вище 2,5\% річних.

Румунія. Уряд Румунії у березні 2020 р. опублікував спеціальну постанову щодо підтримки місцевого бізнесу під час боротьби з пандемією та ії наслідками, яка загалом склала 2\% ВВП країни [16]. Такі заходи були посилені схваленим Єврокомісією 1 квітня 2020 року пакетом на 3,3 млрд євро підтримки економіки Румунії з окремим місцем в ній підтримки сектору МСП у вигляді прямих дотації (грантів) та кредитних гарантій держави [16].

Запроваджена програма державної допомоги по безробіттю для працівників підприємств, які постраждали від пандемії та були вимушені призупинити свою діяльність через встановлені обмеження. Допомога буде складати $75 \%$ від заробітної плати, яку працівник отримував на підприємстві, але не більше середньої заробітної плати (приблизно 1200 євро). Окрім того, 17 квітня 2020 року були внесені зміни до державного бюджету та виділено 200 млн євро на надання підтримки у вигляді мінімальної заробітної плати для мікро підприємців та сімейного бізнесу (460 євро) [24].

У квітні 2020 року була запущена програма «SME INVEST ROMANIA» спеціально для сектору МСП, з метою надання підтримки у вигляді кредитних гарантій державою, без відсоткових та обов'язкових платежів. Для середніх підприємств є можливість отримати пільговий кредит на оборотні кошти до 1 млн євро на 3 роки під 80\% відсоткові гарантії держави, а для малих підприємств та мікропідприємств обсягом 200000 євро та 100000 євро відповідно під 90\% гарантії. Відсотки за кредитами на обігові кошти для MCП обмежені державою трьохмісячним ROBOR (Romanian Interbank Offer Rate) + $2,5 \%$. Також є можливість для малих та середніх підприємств отримати інвестиційних кредит до 2 млн євро під 80\% гарантії держави на 6 років, процентні ставки за якими також обмежені трьохмісячним ROBOR розмірі 2,5\%.

Щодо фіскальних заходів, постановою уряду 33/2020 від 23 березня 2020 року були запроваджені податкові знижки з корпоративного податку на прибуток за I квартал 2020 року для МСП - 10\%, а для великих компаній - 5\%. А вже 23 квітня уряд пролонгував 10\% знижку для усіх платників податку на прибуток за II та III квартали 2020 року [16]. Було відтерміновано сплату місцевих податків - на будівельне, земельне та транспортне обладнання. На час пандемії та 30 днів після завершення карантину за невчасно сплачені податки не нараховується пеня ті інші штрафні санкції. На час надзвичайного стану усі МСП, які отримають спеціальний сертифікат від міністерством економіки, який свідчить про те, що бізнес постраждав від пандемії й її наслідків - звільняється від плати за комунальні послуги, а також плати за оренду офісних площ [16].

3 квітня 2020 р. є можливість відстрочки виплати кредитів до 9 місяців для підприємств, які постраждали від пандемії та які відчули на собі обмеження держави. 
Отже, в розглянутих країнах найбільш популярними механізмами підтримки бізнесу на час карантину є: відстрочка податкових платежів, податкові канікули, компенсація витрат на заробітну плату, забезпечення пільгового кредитування, надання грантів та іншої безповоротної допомоги. Більшість інструментів підтримки бізнесу зосереджено на наданні фінансової підтримки бізнесу у вигляді компенсацій витрат за кредити, грантів, або у вигляді компенсації витрат на заробітну плату. Такі механізми $\epsilon$ найбільш оперативними та відповідно, ефективними у антикризових заходах підтримки малого та середнього бізнесу.

Висновки і перспективи подальших досліджень. Беручи до уваги значний рівень тіньової економіки в Україні, та особливо в секторах, які постраждали найбільше від наслідків пандемії, продовження кризових явищ в економіці, реальні витрати бізнесу та бюджету встановити можна тільки попередньо. Однак, вже зараз станом на вересень 2020 року, в Україні можна спостерігати макрофінансові показники, які свідчать про суттєвий спад в економічній активності. В цих умовах варто переглянути підходи до політики підтримки бізнесу в Україні. Пропонується, базуючись на аналізі сучасного стану екосистеми підтримки бізнесу та досвіді країн ЄС:

посилити компонент фінансової підтримки запровадивши програму надання грантової підтримки для мікро та малих підприємців. така програма може фінансуватись за рахунок коштів програм міжнародної допомоги та за рахунок коштів державного бюджету й розповсюджуватись на підприємців-початківців.

надати можливість розстрочки або компенсації плати по окремих комунальних платежах для підприємств, які найбільше постраждали від пандемії або починають свою діяльність.

посили програму «доступні кредити 5-7-9\%», додавши можливість отримання держаних гарантій.

розширити програму компенсації роботодавцям витрат на оплату праці, на час карантинних заходів, встановивши для найбільш постраждалих секторів бізнесу просту формулу підтримки фондів оплати праці на основі досвіду країн єс.

для туристичної галузі запровадити спеціальні податкові пільги з туристичного збору.

запровадити можливість відтермінування або розстрочки податкових платежів в частині пдв, акцизу, земельних податків, екологічного податку, податку на прибуток, мито, рентної плата.

Такі запропоновані заходи мають потенціал до сприяння відновленню взаємозв'язків між усіма агентами екосистеми бізнесу та дадуть поштовх до розвитку економіки окремих галузей бізнесу та України в цілому.

\section{СПИСОК ВИКОРИСТАНИХ ДЖЕРЕЛ}

1. Moore J. F. Predators and Prey: A New Ecology of Competition. Harvard Business Review. 1993. Vol. 71. № 3. P. 75-86.

2. Moore J. F. The rise of a new corporate form. Washington Quarterly, 1998. Vol. 21(1). P. $167-181$

3. Foster G., Shimizu C., Ciesinski S., Davila A., Zahoor Hassan S., Jia N., Plunkett S., Pinelli M., Cunningham J., Hiscock-Croft R., McLenithan M., Rottenberg L., Morris R., Lee D. (2013) Entrepreneurial Ecosystems Around the Globe and Company Growth Dynamics. Geneva: World Economic Forum

4. Doing Business in Ukraine - World Bank Group. The World Bank. URL: https://www.doingbusiness.org/en/data/exploreeconomies/ukraine (дата звернення: 
10.09.2020).

5. Експрес-опитування бізнесу. Офіційний сайт Європейської Бізнес Асоціації. URL: https://eba.com.ua/ (дата звернення: 21.04.2020)

6. Дослідження стану та перспектив українського бізнесу. Офіційний сайт. URL: https://hvylya.net/ (дата звернення: 21.04.2020)

7. COVID-19: Наслідки для бізнесу та дії за умов кризи Офіційний сайт. URL: https://www.ey.com/uk ua/ (дата звернення: 21.04.2020)

8. Закон України. Офіційний сайт Верховної ради України. URL: https://zakon.rada.gov.ua/laws/show/533-IX\#Text (дата звернення 15.06.2020)

9. Закон України. Офіційний сайт Верховної ради України. URL: https://zakon.rada.gov.ua/laws/show/591-20\#Text (дата звернення 15.06.2020)

10. Аналітична записка. Офіційний сайт Державного центру зайнятості. URL: https://www.dcz.gov.ua/analitics/67 (дата звернення: 20.06.2020)

11. Постанова KMУ. URL: https://www.kmu.gov.ua/npas/pro-vnesennya-zmin-doporyadku-na-a319 (дата звернення: 20.06.2020)

12. Підсумки тижня за результатами програми «Доступні кредити 5-7-9\%». Офіційний сайт Міністерства фінансів України. URL: https://www.mof.gov.ua/uk/news/pidsumki_tizhnia_za_rezultatami_programi_dostupni_kredi ti 5-7-9 299 kreditnikh ugod na 577 miliona griven-2459 (дата звернення: 02.10.2020) 13. Донорські програми. Портал для підприємців. URL: https://sme.gov.ua/program type/programy-mizhnarodnoyi-tehnichnoyi-dopomogy/ (дата звернення: 26.07.2020)

14. Temporary Framework for State aid measures to support the economy in the current COVID-19 outbreak. EUR-Lex. URL: https://eur-lex.europa.eu/legalcontent/EN/TXT/?uri=OJ\%3AJOC_2020_091_I_0001 (дата звернення: 26.07.2020)

15. WDI. The World Bank. URL: https://databank.worldbank.org/source/worlddevelopment-indicators (дата звернення: 26.07.2020)

16. Policy measures taken against the spread and impact of the coronavirus. European Commission. URL: https://ec.europa.eu/info/live-work-travel-eu/health/coronavirusresponse/jobs-and-economy-during-coronavirus-pandemic_en\#state-aid-actions звернення: 30.07.2020)

17. Government and institution measures in response to COVID-19. KPMG. URL: https://home.kpmg/xx/en/home/insights/2020/04/bulgaria-government-and-institutionmeasures-in-response-to-covid.html (дата звернення: 30.07.2020)

18. Микрокредитиране със споделен риск. Сайт FMFIB. https://www.fmfib.bg/bg/fi/20finansirane-sas-spodelyane-na-riska/7-mikrokreditirane-sas-spodelen-risk (дата звернення: 30.07.2020)

19. Решение № 310 от 2020 г. ЕДИНЕН ИНФОРМАЦИОНЕН ПОРТАЛ. https://coronavirus.bg/bg/326 (дата звернення: 30.07.2020)

20. Wage support programme. Website of the Hungarian Government. URL: https://www.kormany.hu/en/ministry-for-national-economy/news/wage-support-programmenow-protects-137-000-persons-jobs (дата звернення: 30.07.2020)

21. Hungary: Tax developments in response to COVID-19. KPMG. URL: https://home.kpmg/xx/en/home/insights/2020/04/hungary-tax-developments-in-response-tocovid-19.html (дата звернення: 31.07.2020)

22. State aid. European Commission. URL: https://ec.europa.eu/commission/presscorner/detail/en/ip 20649 (дата звернення: 31.07.2020) 


\section{REFERENCES}

1. Moore J. F. (1993). Predators and Prey: A New Ecology of Competition. Harvard Business Review, 71(3), 75-86.

2. Moore J. F. (1998). The rise of a new corporate form. Washington Quarterly, 21(1), $167-181$

3. World Economic Forum (2013). Entrepreneurial Ecosystems Around the Globe and Company Growth Dynamics. World Economic Forum. http://www3.weforum.org/docs/WEF_EntrepreneurialEcosystems_Report_2013.pdf

4. The World Bank. (2020, September 10). Doing Business in Ukraine - World Bank Group. https://www.doingbusiness.org/en/data/exploreeconomies/ukraine

5. European Business Association. (2020, April 21). Express business survey. https://eba.com.ua/reaktsiya-biznesu-na-zaprovadzhennya-30-ty-dennogo-karantynu/

6. Hvylya. (2020, April 21). What will happen to Ukrainian business. https://hvylya.net/analytics/204163-shcho-vidbuvatimetsya-z-ukrajinskim-biznesom

7. European Business Association. (2020, April 21). EY "COVID-19: Implications for Business and Crisis Action". https://eba.com.ua/ey-covid-19-naslidky-dlya-biznesu-ta-diyi-zaumov-kryzy/

8. Verkhovna Rada of Ukraine. (2020, June 15). Law of Ukraine On Amendments to the Tax Code of Ukraine and Other Laws of Ukraine Concerning Support to Taxpayers for the Period of Implementing Measures Aimed at Preventing the Occurrence and Spread of Coronavirus Disease (COVID-19). https://zakon.rada.gov.ua/laws/show/533-IX\#Text

9. Verkhovna Rada of Ukraine. (2020, June 15). Law of Ukraine On Amendments to the Tax Code of Ukraine and Other Laws of Ukraine Concerning Additional Support to Taxpayers for the Period of Implementing Measures Aimed at Preventing the Occurrence and Spread of Coronavirus Disease (COVID-19). https://zakon.rada.gov.ua/laws/show/591-20\#Text

10. State Employment Center. (2020, June 20). Analytical and statistical information. https://www.dcz.gov.ua/analitics/67

11. Cabinet of Ministers of Ukraine. (2020, June 20). On amendments to the Procedure for providing financial state support to micro and small businesses. https://www.kmu.gov.ua/npas/pro-vnesennya-zmin-do-poryadku-na-a319

12. Ministry of Finance of Ukraine. (2020, October 02). 13. Results of the week according to the results of the program "Available loans 5-7-9\%". https://www.mof.gov.ua/uk/news/pidsumki_tizhnia_za_rezultatami_programi_dostupni_kredi ti 5-7-9 299 kreditnikh ugod na 577 miliona griven-2459

13. Portal for entrepreneurs. (2020, August 02). Donor programs. https://sme.gov.ua/program type/programy-mizhnarodnoyi-tehnichnoyi-dopomogy/

14. EUR-Lex. (2020, July 02). Temporary Framework for State aid measures to support the economy in the current COVID-19 outbreak. https://eur-lex.europa.eu/legalcontent/EN/TXT/?uri=OJ\%3AJOC 2020091 I 0001

15. The World Bank. (2020, July 26). World Development Indicators. https://databank.worldbank.org/source/world-development-indicators

16. European Commission. (2020, July 30). Policy measures taken against the spread and impact of the coronavirus. https://ec.europa.eu/info/live-work-travel-eu/health/coronavirusresponse/jobs-and-economy-during-coronavirus-pandemic en\#state-aid-actions

17. KPMG. (2020, July 30). Government and institution measures in response to COVID-

19. https://home.kpmg/xx/en/home/insights/2020/04/bulgaria-government-and-institutionmeasures-in-response-to-covid.html 
18. FMFIB. (2020, July 30). Shared risk microcredit. https://www.fmfib.bg/bg/fi/20finansirane-sas-spodelyane-na-riska/7-mikrokreditirane-sas-spodelen-risk

19. SINGLE INFORMATION PORTAL. (2020, July 30). Decision № 310 of 2020 approving the Portfolio Guarantee Program to support the liquidity of micro, small and medium-sized enterprises affected by the emergency situation and the COVID-19 epidemic. https://coronavirus.bg/bg/326

20. Hungarian Government. (2020, July 30). Wage support programme. https://www.kormany.hu/en/ministry-for-national-economy/news/wage-support-programmenow-protects-137-000-persons-jobs

21. KPMG. (2020, July 30). Hungary: Tax developments in response to COVID-19. https://home.kpmg/xx/en/home/insights/2020/04/hungary-tax-developments-in-response-tocovid-19.html

22. European Commission. (2020, July 31). State aid. https://ec.europa.eu/commission/presscorner/detail/en/ip_20_649 